\title{
A new allergic rhinitis therapy (MP29-02*) provides effective and rapid symptom relief for patients who suffer most from the bothersome symptoms of nasal congestion or ocular itch
}

\author{
Wytske Fokkens $^{1 *}$, Peter Hellings ${ }^{2}$, Joaquim Mullol ${ }^{3}$, Ullrich Munzel $^{4}$, Claus Bachert ${ }^{5}$ \\ From The 10th Symposium of Experimental Rhinology and Immunology of the Nose (SERIN 2015) \\ Stockholm, Sweden. 19-21 February 2015
}

\section{Background}

Allergic rhinitis (AR) patients often present with a predominant symptom. Nasal congestion and ocular symptoms have the greatest negative impact on patients' quality of life [1]. Our aim was to assess the efficacy of MP29-02* (a novel intranasal formulation of azelastine hydrochloride [AZE] and fluticasone propionate $[\mathrm{FP}]$ in an advanced delivery system) in seasonal AR (SAR) patients presenting with nasal congestion or ocular itch predominantly compared to AZE, FP or placebo (PLA) nasal sprays.

\section{Methods}

610 patients ( $\geq 12$ yrs old) with moderate/severe SAR were randomized into a double-blind, PLA-controlled, 14-day, parallel-group trial to MP29-02*, AZE FP or PLA nasal sprays (all 1 spray/nostril bid [total daily

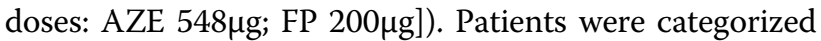
as nasal congestion- or ocular itch-predominant (for those patients with baseline rTOSS $\geq 8$ ) according to maximal symptom scores at baseline. Targeted symptom reduction was assessed for each predominant symptom over the entire 14 day period and on each day.

\section{Results}

Congestion-predominant MP29-02\%-patients experienced 3 times the congestion relief of FP-patients $(\mathrm{p}=0.0018)$ and 5 times the relief provided by AZE $(\mathrm{p}=0.0001)$. AZE and FP did not significantly differ from PLA. Superior congestion relief afforded by MP29-02* in these patients was evident from Day 2 vs FP $(\mathrm{p}=0.0155)$, AZE $(\mathrm{p}=0.0032)$ and
PLA ( $\mathrm{p}=0.0010)$ and sustained for 14 days. The level of relief achieved by MP29-02* patients on Day $2(-0.90)$ was not achieved before Day 9 by either FP or AZE patients. Ocular itch predominant MP29-02*-patients experienced 4 times the ocular itch relief as FP-patients $(\mathrm{p}=0.0026)$ and twice the relief provided by AZE $(\mathrm{p}=0.0551)$. FP did not provide additional ocular itch relief over the placebo response. The level of ocular itch relief achieved by MP29$02 *$ patients on Day $2(-0.93)$ was not achieved before Day 9 by FP patients or before Day 4 by AZE patients.

\section{Conclusion}

Unlike currently available first line therapy, MP29-02* effectively and rapidly reduced nasal congestion and ocular itch in patients suffering predominantly from these symptoms. MP29-02\%'s rapidity and effectiveness in relieving predominant congestion and ocular itch could lead to a reduction in the need for concomitant decongestants and eye drops, respectively and further supports the position of MP29-02* as the drug of choice for the treatment of AR.

* Dymista
Authors' details

${ }^{1}$ Academic Medical Center, Amsterdam, Netherlands. ${ }^{2}$ University Hospital Leuven, Dept of Otorhinolaryngology, Head \& Neck Surgery, Leuven, Belgium. ${ }^{3}$ Hospital Clinic IDIBAPS, CIBERES, Barcelona, Spain. ${ }^{4}$ Meda, Corporate Clinical Affairs, Bad Homburg, Germany. ${ }^{5}$ Ghent University Hospital, Department of Oto-Rhinolaryngology, Ghent, Belgium.

Published: 26 June 2015

${ }^{1}$ Academic Medical Center, Amsterdam, Netherlands

Full list of author information is available at the end of the article 


\section{Reference}

1. Bousquet PJ, Demoly P, Devillier P, Mesbah K, Bousquet J: Impact of allergic rhinitis symptoms on quality of life in primary care.. Int Arch Allergy Immunol 2013, 160(4):393-400.

doi:10.1186/2045-7022-5-S4-P33

Cite this article as: Fokkens et al:: A new allergic rhinitis therapy (MP29$02^{*}$ ) provides effective and rapid symptom relief for patients who suffer most from the bothersome symptoms of nasal congestion or ocular itch. Clinical and Translational Allergy 2015 5(Suppl 4):P33.

Submit your next manuscript to BioMed Central and take full advantage of:

- Convenient online submission

- Thorough peer review

- No space constraints or color figure charges

- Immediate publication on acceptance

- Inclusion in PubMed, CAS, Scopus and Google Scholar

- Research which is freely available for redistribution

Submit your manuscript at www.biomedcentral.com/submit

Biomed Central 